3. Леденева В.В. Идиостиль (к уточнению понятия) // Филологические науки. - № 5. - 2001. $41 \mathrm{c}$.

4. Литературный энициклопедический словарь / под общ.ред. В.М. Кожевникова, П.А. Николаева, М.:Совет. Энцикл. 1987. - 750 с.

5. Тураева 3.Я. Лингвистика текста и категория модальности // Вопросы языкознания. - № 3. 1994. - 114 c.

6. Фролов В.В. Судьбы жанров драматургии: анализ драматических жанров в России XX века М.: Совет. писатель, $1979-424$ с.

7. Хэллидей М.А.К. Лингвистическая функция и литературный стиль // Новое в зарубежной лингвистике. - Вып. 9. - М.: Прогресс, 1980. - 147 с.

8. Хусаинова Л.Т. Трагикомический эффект и характер сюжета в современных башкирских трагикомедиях - Вестник Челябинского государственного университета . 2012. - C 147-150.

9. Langacker R.W. The conceptual basis of cognitive semantics // Language and conceptualization. Eds. J. Nuyts, E. Pederson. - Cambridge: Cambridge University Press, 1999. - P.252.

10. Note on Dickens's life in an addition of Oliver Twist, London: Mandarin Paperbacks, 1991.

11. Robert Elbaz, The Changing Nature of the Self. A Critical Study of the Autobiographic Discourse, London: Croom Helm Ltd., 1988

12. Steve Martin, "Secret passion between the covers", in The Times Saturday Review, August 28, 1992

\title{
Назаров В.И. \\ Проблема ответственности юридических лиц за совершение правонарушений в области безопасности дорожного движения
}

Уральский Финансово-Юридический институт (Россия, Екатеринбург) doi:10.18411/1j2016-4-15

В начале XXI века возможности фиксации правонарушений (в том числе и в области дорожного движения) значительно расширились, появились специальные средства фотовидеофиксации, работающие в автоматическом режиме. Подобные нововведения привели к тому, что перед правоохранительными органами встала проблема привлечения к ответственности за нарушения в области дорожного движения не только физических, но и юридических лиц. Разумеется, юридические лица в данном случае нарушают правила не напрямую, правонарушителем является водитель транспортного средства, представляющий собой физическое лицо. Однако, согласно ч. 1 ст. 2.6.1 Кодекса об административных правонарушениях Российской Федерации (далее КоАП РФ), субъектами ответственности за нарушения в области дорожного движения, зафиксированные специальными камерами, являются собственники транспортных средств. Таким образом, если автомобиль или иное транспортное средство зарегистрированы на юридическое лицо, то оно и ответственно за правонарушение.

Существует ряд других статей КоАП РФ, по которым юридические лица могут быть привлечены к ответственности за нарушения норм и стандартов в области дорожного движения (ст. ст. $11.23,11.32,14.1,14.4 .1)$. Но на практике статистические данные показывают, что, несмотря на существование подобных законодательных норм, основным субъектом ответственности за правонарушения в области обеспечения безопасности дорожного движения остается водитель транспортного средства. По данным ГИБДД, в период с 2004 по 2013 гг. в нашей стране ежегодно в административном порядке наказывалось от 39 млн. до 68 млн. человек. Подавляющим большинством привлеченных к ответственности стали водители, к тому же их процент даже вырос - от 86 \% в 2004 г. до 93 \% в 2013 г. [1].

Проблема ответственности юридических лиц за нарушения в области обеспечения безопасности дорожного движения уже не нова, ей посвятили свои работы многие авторитетные отечественные ученые. Так, профессор В.И. Майоров считает, что «юридические лица и индивидуальные предприниматели, осуществляющие деятельность, связанную с участием в дорожном движении, должны строго исполнять обязанности, возложенные на них Ф3 «О безопасности дорожного движения» и Правилами дорожного движения, а за невыполнение обязанностей нести соответствующую ответственность, особенно при совершении дорожно-транспортных происшествий или создании предпосылки к происшествию» [2, с. 103]. 
Юридическим лицам, а в особенности различным автотранспортным предприятиям, вне зависимости от ведомственной подчиненности и форм собственности необходимо решать задачи по обеспечению безопасности дорожного движения, связанные с организацией профилактической работы с водителями, контролем технического состояния транспортных средств, учетом и анализом дорожнотранспортных происшествий [2, с. 107]. Здесь следует выразить согласие с точкой зрения профессора Б.В. Россинского, который предлагает для повышения эффективности обеспечения безопасности участников дорожного движения, оказывать воздействие «...прежде всего на юридические лица, причастные к решению проблемы обеспечения безопасности дорожного движения» [3, с. 10].

Кроме того, автор статьи полагает, что ответственность юридические лица должны нести не только по факту совершенного дорожно-транспортного происшествия, но и в случае совершения ими противоправных действий на стадии подготовки и обеспечения транспортного процесса. Ведь безопасность дорожного движения включает в себя не только обеспечение безопасности процесса непосредственного транспортного перемещения, но и куда более широкий круг общественных отношений [4, с. 100], в которых немалую роль играют юридические лица. Данный вопрос не является достаточно проработанным по причине отсутствия должного контроля в этой области. Как отмечал Б.В. Россинский: «Административноюрисдикционная практика в области дорожного движения в нашем государстве ориентирована прежде всего на участников дорожного движения, а не на должностных лиц организаций, призванных обеспечить безопасность на автомобильном транспорте, и не на сами эти организации» [3, с. 13].

Развитие в нашей стране рынка пассажирских перевозок, рост численности мелких и средних транспортных предприятий обуславливают необходимость расширения законодательных возможностей по привлечению к ответственности юридических лиц, а также проведения различных профилактических и обучающих мероприятий. Профилактика правонарушений в области дорожного движения должна быть ориентирована прежде всего на должностных лиц, ответственных за организацию безопасности как процесса транспортного перемещения, так и его подготовки.

По мнению В.И. Майорова, «одним из приоритетных направлений деятельности служб по организации безопасности дорожного движения является профилактическая работа непосредственно на автотранспортных предприятиях» [2, с. 108]. Профилактические мероприятия необходимы для формирования правосознания у водителей транспортных средств, повышения уровня знаний Правил дорожного движения, содействия развитию транспортной культуры.

В заключение хотелось бы упомянуть основные обязанности по обеспечению безопасности в области дорожного движения, лежащие на юридических лицах:

1) соблюдать правила обеспечения безопасности перевозок пассажиров и грузов автомобильным и городским наземным электрическим транспортом;

2) организовывать работу водителей в соответствии с требованиями, обеспечивающими безопасность дорожного движения;

3) соблюдать установленный законом режим труда и отдыха водителей;

4) создавать условия для повышения квалификации водителей и других работников, обеспечивающих безопасность дорожного движения;

5) анализировать и устранять причины дорожно-транспортных происшествий и нарушений Правил дорожного движения, с участием принадлежащих им транспортных средств;

6) организовывать проведение обязательных медицинских осмотров и мероприятий по совершенствованию водителями транспортных средств навыков оказания первой помощи пострадавшим в дорожно-транспортных происшествиях;

7) обеспечивать соответствие технического состояния транспортных средств требованиям безопасности дорожного движения и не допускать транспортные средства к эксплуатации при наличии у них неисправностей, угрожающих безопасности дорожного движения;

8) обеспечивать наличие в организации должностного лица, ответственного за обеспечение безопасности дорожного движения и прошедшего в установленном порядке аттестацию на право занимать соответствующую должность; 
9) не допускать к управлению транспортными средствами водителей, находящихся в состоянии опьянения (алкогольного, наркотического или иного), под воздействием лекарственных препаратов, ухудшающих реакцию и внимание, в болезненном или утомленном состоянии, ставящем под угрозу безопасность движения, не имеющих страхового полиса обязательного страхования гражданской ответственности владельца транспортного средства [5].

Необходимо повысить эффективность работы по соблюдению требований законодательства в области обеспечения безопасности дорожного движения юридическими лицами, имеющими в собственности транспортные средства, в особенности транспортными компаниями. Это будет способствовать снижению аварийности, обеспечению безопасности участников дорожного движения, которая в свою очередь «является составной частью задач обеспечения личной безопасности, решения демографических, социальных и экономических проблем, повышения качества жизни и содействия региональному развитию» [6].

\section{Список используемых источников информации}

1. Показатели состояния безопасности дорожного движения. ГИБДД Российской Федерации: официальный сайт. URL: http://www.gibdd.ru/stat/ (дата обращения 22.03.2016).

2. Майоров В.И.. К вопросу об ответственности юридических лиц в сфере безопасности дорожного движения // Татищевские чтения: актуальные проблемы науки и практики. Материалы XII Международной научно-практической конференции. - 2015. - С. 102-108.

3. Россинский Б.В. Административные наказания в сфере дорожного движения и аварийности на автомобильном транспорте / Б.В. Россинский // Административное право и процесс. - 2014. - № 5. - С. 8-17.

4. Майоров В.И. Содержание понятия «Безопасность дорожного движения»: теоретические основы / В.И. Майоров // Вестник Южно-Уральского государственного университета. - 2012. № 7 (266). - C. 99-101.

5. О Правилах дорожного движения: постановление Правительства РФ от 23 октября 1993 г. № 1090 // Собрание актов Президента и Правительства РФ. - 1993. - № 47. - Ст. 4531.

6. Постановление Правительства РФ от 3.10.2013 г. N 864 (ред. от 29.10.2015) «О федеральной целевой программе «Повышение безопасности дорожного движения в 2013 - 2020 годах»// Собрание законодательства РФ. - 2013. - № 41. - Ст. 5183.

\section{Отрах В.В., Самойлов М. А. \\ Функциональная определенность инновационного менеджмента}

Московский технологический институт (Россия, Москва) doi:10.18411/lj2016-4-16

Функциональная определенность инновационного менеджмента, выраженная в своевременном мониторинге организационных изменений и нацеленности новшества на повышение результативности, формируется под влиянием появления совершенно новых форм организации бизнеспроцессов как внутри хозяйствующего субъекта, так и во взаимодействии между такими субъектами. В таком случае, стираются границы между разными функциональными подразделениями внутри предприятия, между самим предприятием и поставщиками, потребителями и конкурентами. Примером таких инновационных организационных структур могут служить формирование вне-иерархических, междисциплинарных групп, основание стратегических альянсов, появление информационных организационных средств управления.

Способность предприятий адаптироваться к стремительным изменениям внешней среды, мобильность организационной структуры, гибкость аппарата управления, предприимчивость руководства индивидуального или корпоративного хозяйствующего субъекта определяющие качества, формирование которых составляет основу 